PUBLIK: Jurnal Manajemen Sumber Daya Manusia, Administrasi dan Pelayanan Publik Sekolah Tinggi Ilmu Administrasi Bina Taruna Gorontalo Volume VI Nomor 2 Desember 2019

\title{
FAKTOR-FAKTOR PENGHAMBAT PARTISIPASI MASYARAKAT DALAM PELAKSANAAN PROGRAM REBOISASI DI KECAMATAN BULANGO ULU KABUPATEN BONE BOLANGO
}

\author{
Fatmah Nento $^{1} \&$ Nolfi S. Tueno ${ }^{2}$ \\ STIA Bina Taruna Gorontalo \\ bukujurnalstia@binataruna.ac.id ${ }^{1} \& \underline{\text { nolfitueno@gmail.com }}{ }^{2}$
}

\begin{abstract}
ABSTRAK
Penelitian ini bertujuan untuk mengetahui Faktor-Faktor Penghambat Partisipasi Masyarakat dalam Pelaksanaan Program Reboisasi di Kecamatan Bulango Ulu Kabupaten Bone Bolango. Penelitian ini menggunakan jenis penelitian deskriptif kualitatif. Teknik pengumpulan data yang digunakan adalah teknik Observasi, Wawancara dan pencatatan data sekunder.

Hasil penelitian menunjukkan bahwa: Dilihat dari faktor pengetahuan belum optimal atau belum menunjang. Karena sebagian besar masyarakat desa di Kecamatan Bulango memiliki pendidikan yang rendah, dimana rata-rata pendidikan masyarakat adalah tidak lulus SD, dan tidak pernah mengikuti pelatihan-pelatihan. Dilihat dari faktor kesadaran masyarakat masih rendah atau kurang menunjang. Karena sebagian besar masyarakat tani sering membuka lahan, sehingga lahan-lahan atau hutan-hutan sebagian telah menjadi tandus atau beralih fungsi dari hutan penyangga alam menjadi lahan tanam. Dilihat dari faktor kesiapan masyarakat masih rendah atau kurang menunjang. Karena masyarakat berpandangan bahwa pelaksanaan program reboisasi bertolak belakang dengan mata pencaharian masyarakat sebagai petani yang selalu berpindah-pindah lahan untuk digarafnya.Secara keseluruan penelitian mengenai Faktor-Faktor Penghambat Partisipasi Masyarakat Dalam Pelaksanaan Program Reboisasi yang di lihat dari faktor pengetahuan, faktor keadaran masyarakat dan faktor kesiapan masyarakat masih rendah atau kurang mendukung pelaksanaan program reboisasi di Kecamatan Bulango Ulu Kabupaten Bone Bolango.

Adapun hal-hal yang disarankan dalam penelitian ini yakni perlunya pemerintah Diharapkan kepada pemerintah daerah khususnya Dinas Kehutanan Kabupaten Bone Bolango memperhatikan kendala-kendala yang dapat menghambat pelaksanaan program reboisasi, dan tidak kala pentingnya dalam penelitian ini adalah masalah pengetahuan, kesadaran masyarakat, dan kesiapan masyarakat turut mempengaruhi pelaksanaan program reboisasi.
\end{abstract}

\section{Kata Kunci: Partisipasi; Masyarakat; Program Reboisasi}

PENDAHULUAN

Pemerintah merupakan

lembaga tertinggi yang mengelola seluruh aset yang menjadi milik Negara Kesatuan Republik
Indonesia, dimana salah satu aset yang memerlukan pengelolaan dengan baik adalah hutan dan lingkungan karena kehidupan manusia sangat bergantung kepada 
kelestarian alam sekitarnya. Apabila fungsi hutan dan lingkungannya mengalami suatu masalah seperti perusakan oleh pihak-pihak yang tidak bertanggung jawab maka kelestarian dan keasriannya akan terganggu, dimana ekosistem dalam aliran sungai (DAS) pun akan mengalami ketidakseimbangan alam.

Salah satu agenda yang dilakukan oleh pemerintah dalam melestarikan fungsi hutan dan lingkungan adalah Program Gerakan Nasional Rehabilitasi Hutan dan Lahan (GN-RHL). Gerakan ini telah dituangkan dalam Peraturan Pemerintah Republik Indonesia Nomor 76 Tahun 2008 Tentang Rehabilitasi Dan Reklamasi Hutan. Dimana tujuannya adalah melaksanakan program reboisasi.

Rehabilitasi hutan dan lahan adalah upaya untuk memulihkan, mempertahankan, dan meningkatkan fungsi hutan dan lahan sehingga daya dukung, produktivitas dan peranannya dalam mendukung sistem penyangga kehidupan tetap terjaga. Reklamasi hutan adalah usaha untuk memperbaiki atau memulihkan kembali lahan dan vegetasi hutan yang rusak agar dapat berfungsi secara optimal sesuai dengan peruntukannya. Hutan dan lahan kritis adalah hutan dan lahan yang berada di dalam dan di luar kawasan hutan yang sudah tidak berfungsi lagi sebagai media pengatur tata air dan unsur produktivitas lahan sehingga rnenyebabkan terganggunya keseimbangan ekosistem DAS.

$$
\text { Untuk mengembalikan }
$$

keseimbangan tersebut maka dilakukan penghijauan kembali, dimana penghijauan adalah upaya pemulihan lahan kritis di luar kawasan hutan untuk mengembalikan fungsi lahan. Untuk Kabupaten Bone Bolango itu sendiri pelaksanaan program Rehabilitasi Dan Reklamasi Hutan atau sering disebut dengan program reboisasi di lakukan pada tahun 2010 .

Pemulihan tersebut diistilahkan sebagai program reboisasi yaitu upaya penanaman jenis pohon hutan pada kawasan hutan rusak yang berupa lahan kosong, alang-alang, atau semak belukar untuk mengembalikan fungsi hutan. Reboisasi adalah suatu cara untuk melestarikan kembali alam yang telah mengalami kerusakan atau perusakan sehingga menjadi tandus, baik oleh alam itu sendiri melalui bencana alam seperti gempa bumi, gunung meletus dan banjir maupun oleh perilaku manusia yang oleh kerakusan demi menguntungkan diri dan orang lain telah tidak memperhatikan bagaimana seharusnya suatu lingkungan dijaga dan dipelihara untuk kemaslahatan seluruh umat manusia.

Tindakan reboisasi adalah mengembalikan fungsi hutan atau menghutankan kembali tanah yang tandus dengan penanaman pohonpohon tertentu, dimana hal ini dimaksud untuk menghijaukan suatu daerah yang telah dimanfaatkan secara tidak bertanggung jawab oleh perambah hutan baik untuk digunakan sebagai lahan tanam maupun yang sengaja digundulkan untuk diambil pokok-pokok pohon yang telah hidup bertahun-tahun di suatu daerah. Salah satu kelemahan para penebang hasil hutan atau perambah hutan adalah tidak melakukan rehabilitasi lahan dan reklamasi hutan dengan menanam 
tanaman atau pohon pengganti yang telah ditebang dalam areal yang cukup luas. Akibat dari penebangan liar ini menyebabkan lahan-lahan menjadi tandus, sehingga saat musim hujan tiba dengan curah hujan yang ekstrim, maka kemungkinan besar daerah itu akan mengalami tanah longsor, yang tentu saja akan mengganggu aktivitas sosial, ekonomi maupun budaya masyarakat itu sendiri.

Walaupun peraturan dengan sanksi yang cukup berat telah diundangkan, tetapi perambahan hutan terus saja terjadi, sehingga lahan-lahan menjadi tandus dan hutan tidak berfungsi dengan baik sebagai penyangga alam. Agaknya peraturan yang ada tidak menimbulkan kesadaran bagi perambah liar bahwa lahan-lahan yang menggundul dapat mengakibatkan bencana bukan saja bagi masyarakat di sekitar lahanlahan tandus tersebut tetapi juga berakibat lebih luas yang akan menimpa hingga daerah-daerah yang dilalui bencana seperti banjir.

Adapun yang dibutuhkan untuk suksesnya program reboisasi adalah ketegasan dari pemerintah daerah dalam hal perizinan dan melakukan pengawasan secara ketat kepada pelaksanaan pemanfaatan hasil hutan dengan ketentuan bahwa kewajiban bagi mereka adalah melakukan rehabilitasi dan reklamasi hutan atau lahan yang telah dimanfaatkan tersebut. Dan partisipasi masyarakat tentu merupakan suatu keberhasilan program reboisasi yang digagas oleh pemerintah. Selain itu, pengenaan sanksi pidana berat bagi yang tidak mematuhi ketentuan sesuai dengan peraturan yang berlaku harus menjadi acuan yang ketat agar tidak ada yang bermain-main dengan peraturan tentang pelestarian alam melalui rehabilitasi dan reklamasi hutan.

Walaupun tujuan program reboisasi yang dilakukan oleh pemerintah adalah untuk mengembalikan fungsi hutan demi kepentingan bersama, tetapi selalu saja ada pihak-pihak yang tidak bertanggung jawab melakukan perusakan hutan-hutan atau lahanlahan, baik secara diam-diam karena telah mendapatkan izin maupun yang tidak berizin dari pemerintah.

Oleh sebab itu, dinas kehutanan harus terus melakukan sosialisasi kepada masyarakat yang menempati lahan-lahan terutama di lereng-lereng gunung agar mereka ikut dalam program penghijauan kembali lahan-lahan dengan menanam pohon-pohon tertentu yang telah mengalami kritis berkepanjangan akibat pembukaan lahan sebagai lahan tanam, juga masyarakat baru mempunyai rencana untuk merambah lahan-lahan atau hutan-hutan yang sangat diminati karena kandungan tanah yang baru merupakan lahan yang paling subur untuk ditanami, dimana hasilnya akan sangat memuaskan bagi masyarakat tani. Maka tugas bersama yang harus menjadi perhatian adalah memelihara hutan atau lahan yang telah digunakan dan mengembalikan fungsinya sebagaimana peruntukannya, dimana pemeliharaan hutan adalah kegiatan untuk menjaga, mengamankan, dan. meningkatkan kualitas tanaman hasil kegiatan reboisasi, penghijauan jenis tanaman, dan pengayaan tanaman. Oleh karena itu sangat dibutuhkan partisipasi masyarakat dalam pelaksanaan program reboisasi yang 
dilakukan oleh pemerintah, karena keberhasilan program reboisasi yang digagas oleh pemerintah sangat ditentukan oleh sejauhmana partisipasi masyarakat terhadap program tersebut.

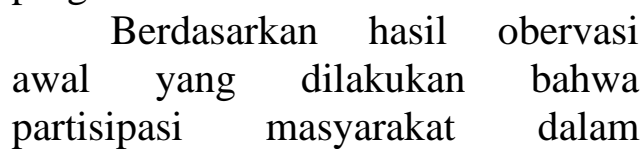
pelaksanaan program reboisasi di Kecamatan Bulango Ulu Kabupaten Bone Bolango masih rendah, hal ini disebabkan oleh beberapa faktor yang menjadi penghambat seperti pengetahuan masyarakat terhadap program reboisasi masih rendah, karena rata-rata masyarakat yang ada di Kecamatan Bulango Ulu khususnya yang di desa Owata yang menjadi desa di laksanakannya program reboisasi ini pendidikannya tidak lulus SD, dan masih kurang mendapatkan informasi mengenai program reboisasi, kondisi inilah yang menjadi kendala bagi masyarakat untuk berpartisipasi dalam pelaksanaan program reboisasi yang dilakukan oleh pemerintah melaui Dinas Kehutanan dan Pertambangan Kabupaten Bone Bolango.

Kesadaran masyarakat terhadap pelaksanaan program reboisasi masih kurang, hal ini dapat dilihat dari sebagian lahan-lahan atau hutan-hutan dan lingkungan yang ada di daerah ini telah menjadi tandus atau beralih fungsi dari hutan penyangga alam menjadi lahan tanam. Masyarakat dengan sering melakukan pembukaan lahan-lahan untuk dijadikan lahan tanam baru karena unsur hara dikandung tanah merupakan lahan subur untuk ditanami. Kesiapan masyarakat dalam pelaksanaan program reboisasi masih rendah. Hal ini dapat ditunjukan oleh masih adanya perilaku masyarakat yang menolak program reboisasi karena menganggap bahwa program ini mengganggu atau menyempitkan lahan tanam yang sedang digarap, dimana akibat ketidaktahuan ini maka sebagian besar masyarakat membuka lahan-lahan menyangga alam dari akibat erosi yang mungkin terjadi untuk kepentingan kehidupan mereka. Kondisi inilah yang menjadi kendala bagi masyarakat untuk berpartisipasi dalam pelaksanaan program reboisasi yang dilaksanakan oleh pemerintah selama ini.

Berdasarkan latar belakang tersebut di atas, maka diajukan judul "Faktor-Faktor Penghambat Partisipasi Masyarakat Dalam Pelaksanaan Program Reboisasi Di Kecamatan Ulu Kabupaten Bone Bolango"

\section{PERMASALAHAN}

Berdasarkan identifikasi masalah di atas, maka rumusan masalah dalam penelitian ini FaktorFaktor Apakah yang Menghambat Partisipasi Masyarakat Dalam Pelaksanaan Program Reboisasi di Kecamatan Ulu Kabupaten Bona Bolango?

\section{TUJUAN DAN MANFAAT PENELITIAN}

Adapun tujuan penelitian ini adalah untuk menggambarkan Faktor-Faktor Penghambat Partisipasi Masyarakat Dalam Pelaksanaan Program Reboisasi di Kecamatan Ulu Kabupaten Bone Bolango. 


\section{Manfaat Penelitian}

Manfaat yang diharapkan dari penelitian ini adalah:

1. Secara Teoritis, penelitian ini diharapkan dapat bermanfaat secara teoritis bagi pengembangan ilmu pengetahuan, khususnya ilmu administrasi dan menjadi referensi bagi peneliti lain yang mempunyai minat yang sama.

2. Secara Praktis, penelitian ini diharapkan bermanfaat bagi para stakeholder, khususnya Dinas Kehutanan Kabupaten Bone Bolango.

\section{Fokus Penelitian}

Adapun fokus dalam penelitian mengenai Faktor-Faktor Penghambat Partisipasi Masyarakat Dalam Pelaksanaan Program Reboisasi Di Kecamatan Bolango Ulu Kabupaten Bone Bolango, yang ditinjau dari pengetahuan, kesadaran masyarakat, dan kesiapan masyarakat, dioperasionalkan sebagai berikut:

\section{Pengetahuan}

Yaitu tingkat pendidikan formal maupun non formal yang dimiliki oleh masyarakat dalam mendukung pelaksanaan progam reboisasi Di Kecamatan Bolango Ulu Kabupaten Bone Bolango.

\section{Kesadaran Masyarakat}

Yaitu perilaku atau sikap yang dimiliki oleh masyarakat dalam mendukung keberhasilan pelaksanaan program reboisasi Di Kecamatan Bolango Ulu Kabupaten Bone Bolango.

\section{Kesiapan Masyarakat}

Yaitu kesediaan dan penerimaan masyarakat terhadap lahan dan hutan untuk pelaksanaan program reboisasi di Kecamatan Bolango Ulu Kabupaten Bone Bolango.

\section{METODE PENELITIAN}

\section{Jenis Penelitian}

Jenis penelitian yang digunakan dalam mengkaji FaktorFaktor Penghambat Partisipasi Masyarakat Dalam Pelaksanaan Program Reboisasi Di Kecamatan Bolango Ulu Kabupaten Bone Bolango, yakni jenis penelitian deskriptif dengan pendekatan kualitatif. Sumber data dalam penelitian ini berasal dari data primer dan data sekunder. Sedang pengumpulan data dalam penelitian ini, teknik yang digunakan terdiri dari observasi, wawancara dan dokumentasi. Sementara teknik analisis data dilakukan dalalm tahap reduksi data, penyajian data, dan penarikan kesimpulan.

\section{HASIL PENELITIAN DAN PEMBAHASAN}

Berdasarkan analisis hasil wawancara dari fokus kajian penelitian ini mengenai FaktorFaktor Penghambat Partisipasi Masyarakat Dalam Pelaksanaan Program Reboisasi Di Kecamatan Ulu Kabupaten Bone Bolango yang di lihat dari segi pengetahuan, kesadaran masyarakat, dan kesiapan masyarakat masih rendah atau kurang mendukung pelaksanaan program reboisasi.

Pengetahuan dalam penelitian ini merupakan tingkat pendidikan formal maupun non formal yang dimiliki oleh masyarakat dalam mendukung pelaksanaan progam reboisasi Di Kecamatan Bolango Ulu Kabupaten Bone Bolango. Hasil penelitian menunjukan bahwa Faktor-Faktor Penghambat Partisipasi Masyarakat Dalam 
Pelaksanaan Program Reboisasi Di Kecamatan Ulu Kabupaten Bone Bolango yang dilihat dari faktor pengetahuan belum optimal atau belum menunjang. Karena sebagian besar masyarakat desa di Kecamatan Bulango memiliki pendidikan yang rendah, dimana rata-rata pendidikan masyarakat adalah tidak lulus SD, dan tidak pernah mengikuti pelatihan-pelatihan yang berhubungan dengan usaha yang digelutinya untuk memperluas wawasan pengetahuan. Kondisi inilah yang menjadi kendala bagi masyarakat untuk ikut terlibat dalam setiap program pembangunan, termasuk didalamnya adalah berpartisipasi dalam pelaksanaan program reboisasi di Kecamatan Bulango Ulu Kabupaten Bone Bolango.

Kesadaran masyarakat dalam penelitian ini merupakan perilaku atau sikap yang dimiliki oleh masyarakat dalam mendukung keberhasilan pelaksanaan program reboisasi Di Kecamatan Bolango Ulu Kabupaten Bone Bolango. Hasil penelitian menunjukan bahwa Faktor-Faktor Penghambat Partisipasi Masyarakat Dalam Pelaksanaan Program Reboisasi Di Kecamatan Ulu Kabupaten Bone Bolango yang dilihat dari faktor kesadaran masyarakat masih rendah atau kurang menunjang. Hal ini terjadi karena sebagian besar masyarakat desa di Kecamatan Bulango Ulu kurang memiliki kesadaran, kondisi ini dapat ditunjukan oleh kenyataan dilapangan bahwa sebagian besar masyarakat tani sering membuka lahan, sehingga lahan-lahan atau hutan-hutan sebagian telah menjadi tandus atau beralih fungsi dari hutan penyangga alam menjadi lahan tanam. Padahal pemerintah tidak secara langsung sudah melarang masyarakat untuk membuka lahan baru yaitu melalui program reboisasi, karena membukan lahan baru yang berpindah-pindah akan memiliki akibat terjadinya lahan menjadi gundul dan menyebabkan erosi. Namun masyarakat kurang peduli terhadap hal tersebut. Kondisi inilah yang menjadi kendala bagi masyarakat untuk berpartisipasi dalam pelaksanaan program reboisasi di Kecamatan Bulango Ulu Kabupaten Bone Bolango.

Kesiapan masyarakat dalam penelitian ini merupakan kesediaan dan penerimaan masyarakat terhadap lahan dan hutan untuk pelaksanaan dalam program reboisasi di Kecamatan Bolango Ulu Kabupaten Bone Bolango. Hasil penelitian menunjukan bahwa Faktor-Faktor Penghambat Partisipasi Masyarakat Dalam Pelaksanaan Program Reboisasi Di Kecamatan Ulu Kabupaten Bone Bolango yang dilihat dari faktor kesiapan masyarakat masih rendah atau kurang menunjang. Hal ini terjadi karena menurut pandangan masyarakat bahwa pelaksanaan program reboisasi bertolak belakang dengan mata pencaharian masyarakat sebagai petani yang selalu berpindahpindah lahan untuk digarafnya. Selain itu masyarakat mempunyai pandangan bahwa program reboisasi ini akan mengambil atau merampas lahan-lahan yang masyarakat garaf sekarang ini, masyarakat juga berpikir bahwa program reboisasi ini akan memindahkan masyarakat tani ke areal atau pemukiman yang lain, yang jauh dari tempat tinggal mereka. Hal inilah yang menjadi 
kendala bagi masyarakat tani untuk berpartisipasi dalam pelaksanaan program reboisasi di Kecamatan Bulango Ulu Kabupaten Bone Bolango.

Dari keempat fokus yang telah dijabarkan melalui pembahasan hasil penelitian, menunjukkan bahwa penelitian mengenai Faktor-Faktor Penghambat Partisipasi Masyarakat Dalam Pelaksanaan Program Reboisasi Di Kecamatan Bulango Ulu Kabupaten Bone Bolango yang di lihat dari faktor pengetahuan, faktor kesadaran masyarakat, dan faktor kesiapan masyarakat, masih rendah atau kurang mendukung pelaksanaan program reboisasi di Kecamatan Bulango Ulu Kabupaten Bone Bolango.

\section{SIMPULAN}

Berdasarkan hasil penelitian
dan pembahasan yang telah
dipaparkan sebelumnya, peneliti
mengambil beberapa simpulan
sebagai berikut.

1. Dilihat dari faktor pengetahuan belum optimal atau belum menunjang. Karena sebagian besar masyarakat desa di Kecamatan Bulango memiliki pendidikan yang rendah, dimana rata-rata pendidikan masyarakat adalah tidak lulus SD, dan tidak pernah mengikuti pelatihanpelatihan.

2. Dilihat dari faktor kesadaran masyarakat masih rendah atau kurang menunjang. Karena sebagian besar masyarakat tani sering membuka lahan, sehingga lahan-lahan atau hutan-hutan sebagian telah menjadi tandus atau beralih fungsi dari hutan penyangga alam menjadi lahan tanam.

3. Dilihat dari faktor kesiapan masyarakat masih rendah atau kurang menunjang. Karena masyarakat berpandangan bahwa pelaksanaan program reboisasi bertolak belakang dengan mata pencaharian masyarakat sebagai petani yang selalu berpindahpindah lahan untuk digarafnya. Selain itu masyarakat mempunyai pandangan bahwa program reboisasi ini akan mengambil atau merampas lahan-lahan yang masyarakat garaf sekarang saat ini, dan memindahkan masyarakat tani ke areal atau pemukiman yang lain, yang jauh dari tempat tinggal mereka.

4. Secara keseluruan penelitian mengenai Faktor-Faktor Penghambat Partisipasi Masyarakat Dalam Pelaksanaan Program Reboisasi yang di lihat dari faktor pengetahuan, faktor keadaran masyarakat dan faktor kesiapan masyarakat masih rendah atau kurang mendukung pelaksanaan program reboisasi di Kecamatan Bulango Ulu Kabupaten Bone Bolango.

\section{SARAN}

Dari kesimpulan-kesimpulan di atas, peneliti mengajukan saransaran sebagai berikut:

1. Perlunya pemerintah desa dapat memberikan kesempatan kepada masyarakat tani untuk diikutsertakan dalam setiap pertemuan seperti sosialisasi, penyuluhan program reboisasi, baik ditingkat desa maupun kecamatan. Agar masyarakat dapat memperoleh pengalaman, 
wawasan yang luas mengenai program reboisasi.

2. Perlunya pemerintah desa dan kecamatan menanamkan kesadaran kepada masyarakat untuk ikut berpartisipasi dalam program reboisasi, dan sedapat mungkin untuk menyampaikan manfaat dan dampak dari pelaksanaan program reboisasi.

3. Perlunya pemerintah desa dan kecamatan dapat memberikan pemahaman dan sugesti kepada masyarakat bahwa program reboisasi yang dilaksanakan oleh pemerintah memiliki dampak yang besar bagi masyarakat pada umumnya. Dan pemerintah tidak akan pernah mengambil hak-hak rakyat. Sehingga masyarakat akan memiliki kesiapan terhadap pelakasanaan program reboisasi.

\section{DAFTAR PUSTAKA}

Abdussamad, Zuchri. 2014. Kompetensi Aparat Dalam Pelayanan Publik. Yogyakarta: Deepublish.

Ali, Faried. 2007. Metodologi Penelitian Sosial dalam Bidang Ilmu Administrasi dan Pemerintahan. Cet. Pertama. Jakarta: PT. Raja Grafindo Persada.

Badudu, Jusuf dan Sutan Mohammad Zain. 1994. Kamus Umum Bahasa Indonesia. Jakarta: Pustaka Sinar Harapan.

Budiardjo, Miriam. 2014. Pengantar Ilmu Politik. Jakarta: Universitas Terbuka.

Echols, John M., dan Shadily, Hassan. 2010. Kamus Inggris Indonesia, Jakarta: PT. Gramedia Pustaka Utama.
Gie, Liang. 2010. Pengertian, Kedudukan dan Perincian Administrasi. Yogyakarta: Direvisi oleh Sutarto. Liberty.

Hubeis, A.V.S. 2011. Partisipasi Masyarakat Dalam Pembangunan. LPPM IPB. Bogor.

Kaji, Yulianto. 2008. Impementasi Kebijakan Publik, Dalam Perpektif Realitas. Tulung Agung: Cahaya Abadi.

Sastrohadiwiryo, Siswanto B. 2011. Manajemen Tenaga Kerja Indonesia: Pendekatan Administrasi Dan Operasional. Jakarta: Bumi Aksara.

Sastropoerto, R. 2011. Partisipasi Komunikasi Persuasi dan Disiplin dalam Pembangunan Nasional. Bandung: Alumni.

Siagian, P. Sondang. 2011. Patologi Birokrasi: Analisis, Identifikasi Dan Terapinya. Jakarta: Ghalia Indonesia.

Silalahi, Ulbert. 2013. Studi Tentang Ilmu Administrasi: Konsep, Teori Dan Dimensi. Jakarta: Ghalia Indonesia.

Simon, Herbert A. 2004. Administrative Behavior: Perilaku Administral. Jakarta: Bumi Aksara.

Soetrisno. 2014. Menuju Masyarakat Partisipatif. Penerbit Karnisius. Yogyakarta.

Keban, Yaremis. 2009. Indikator Kinerja Pemda: Pendekatan Manajemen dan Kebijakan. Yogyakarta: (makalah)

Kerlinger, Fred N. 2009. Foundation Of Behavioral Research. Rinehart And Winston Inc. Terjemahan Gajah Mada University Pers. 
Mardiasmo. 2009. Akuntansi Sektor

Publik. Edisi IV. Yogyakarta: Andi.

Moleong, Lexy. 2016. Metodologi Penelitian Kualitatif. Edisi Revisi, Cet. Keduapuluhsatu. Bandung: PT. Remadja Rosdakarya.

Pasolong, Harbani. 2013. Teori Administrasi Publik. Bandung: Alfabeta.

Siagian, Sondang. 2012. Kerangka Dasar Ilmu Administrasi. Jakarta: Rineka Cipta.

Silalahi, Ulbert. 2010. Studi Tentang Ilmu Administrasi. Bandung: Sinar Baru.

Sugiyono. 2014. Metode Penelitian Kuantitaitf Kualitaitif dan $R \& D$. Bandung: Alfabeta

\section{Sumber Lain:}

Undang-Undang RI nomor 41 tahun 1999 tentang Kehutanan

Peraturan Pemerintah Republik Indonesia Nomor 24 Tahun 2010 Tentang Penggunaan Kawasan Hutan

Peraturan Pemerintah Republik Indonesia Nomor 76 Tahun 2008 Tentang Rehabilitasi Dan Reklamasi Hutan.

Peraturan Pemerintah Republik Indonesia Nomor 58 Tahun 2007 Tentang Perubahan Atas Peraturan Pemerintah Nomor 35 Tahun 2002 Tentang Dana Reboisasi. 